\title{
Preconditioning the Greenland Sea for deep convection: Ice formation and ice drift
}

\author{
Martin Visbeck,' Jürgen Fischer, and Friedrich Schott \\ Institut fïr Meercskunde. Kicl, Germany
}

\begin{abstract}
The role of sea ice in preconditioning the mixed layers of the central Greenland Sea for deep convection is investigated, with particular emphasis on the formation of the "Nordbukta." The opening of the ice free bay in late January 1989 indicated that the upper layer was well preconditioned for deep convection which reached down to $15(1) 0 \mathrm{~m}$ depth in March 1989. We propose that the ice free bay occurred due to diminishing new icc formation without extensive ice melt. A key process is wind-driven ice drift to the southwest, as observed by upward looking acoustic Doppler current profilers, which will alter the upper ocean freshwater budget when an icc volume gradient along the ice-drift direction exists. We investigated the importance and effects of such an icc-driftinduced freshwater loss on upper ocean properties using an ice-ocean mixed-layer model. Observed temperature and salt profiles from December 1988 served as initial conditions, and the model was integrated over the winter season. Given the one-dimensional physics and climatological surface fluxes, the model was not able to produce a reasonable ice and mixid-layer evolution. However, allowing ice drift to reduce the local ice thickness improved the icc-ocean model performance dramatically. An average icc export of $5-8 \mathrm{~mm} \mathrm{~d}{ }^{1}$ was needed to be consistent with the observed evolution of mixed-layer properties and ice cover. Using the same fluxes and ice export, but initial conditions from the "Is Odden" region, yielded ice cover throughout the winter over a shallow mixed layer. both of which are consistent with the observations from the Odden region.
\end{abstract}

\section{Introduction}

The process of decpwater formation has received increasing attention in the context of understanding the thermohaline occan circulation and its variability. Process-oriented studies embedeled in gyre-scale hydrographic surveys have been carricd out in the Greenland Sea (GS) during the last decade [Clurke et al., 1990; GSP Group, 1990], and observations of ongoing convection [Rhein, 1991; Scholl et al., 1993] and remnants of decp-mixed water columns [Rudels et al., 1989] received much attention. This study addresses the question of how the upper water column is preconditioned for deep or intermediate convection below 200-300 m depth. We distinguish hetween a spatial, regional preconditioning, i.e., a domelike structure of isopycnals yielding minimum stratification in the center of a cyclonic gyre, and the erosion of the upper ocean stratification due to air-sea fluxes. The latter determines the onset and strength of deep convection, while the former sets the favorable locations.

Since the turn of the century, water mass distributions in the GS were known, and Nansen [1906] proposed that the GS gyre was a dcepwater formation site because of small differences between surface and dcepwater properties. However, in the carly 1970s the lack of observed deep-mixed profiles and closer inspection of water mass properties supported the idea of decpwater formation by double-diffusive internal mixing [Car

Nou at Center for Meteorology and Physical Occanography, Massachusi:lts Institute of Technology. Cambridge.

Copyright 1945 by the American Geophysical Union.

Paper number $95 \mathrm{JC}(0) 1611$.

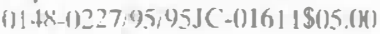

mack and Aagaurd, 1973; McDougall. 1983]. During the same time, Killworth [1983] suggested that there was still a reasonable statistical probability that small-scalc, deep-mixed chimncys were just missed by the (few) winter stations gathered up to that time.

Since 1988, when Rudels et al. [1989] observed remnants of mixing down to $1500 \mathrm{~m}$, there has been a renaissance of "classical" ideas on deep- and intermediate-water formation by surface-forced convection. Rudels [1990] proposed ice formation and subsequent brinc rejection as the processes to initiate deep convection ("haline convection"), while Häkkinen [1 987] cmphasized that ice edge upwelling might be important to enhance dcep mixing. However, Schott et al. [1993] deduced from moored and ship observations that the intermediatc convection during March 1989 down to $15(10 \mathrm{~m}$ depth was dominantly "thermally" driven. and no ice was in the immediate vicinity of the convection site

The role of the ice is critical, since it provides an effective buoyancy loss due to brinc release when new ice is formed, and, on the other hand, ice melting has a dramatic stabilizing effect. Therefore the evolution of mixed-layer properties and ice thickness during the winter season deserves careful investigation.

The climatological evolution of the ice cover was described by Vinje [1977] and reviewed by Walhams [1981] as follows. In the central GS the icc cover shows basically the following three phases: (I) ice free conditions during the summer months (June-October): (2) rapid castward propagation of the marginal ice zonc (MIZ) during early winter (November-January); and (3) in somc years, opcning of an ice free bay in late winter (February-April). Whilc the first two phases are more or less observed every year, the shape of the MIZ in late winter varies 


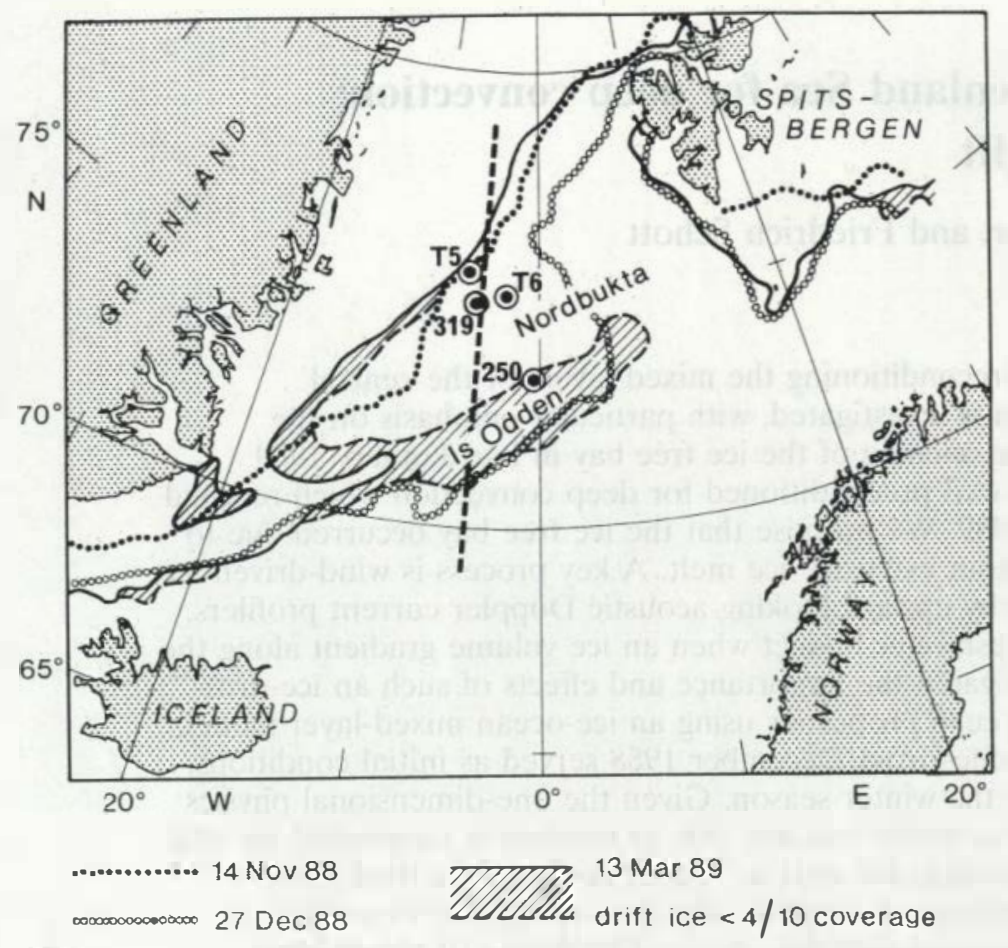

a.

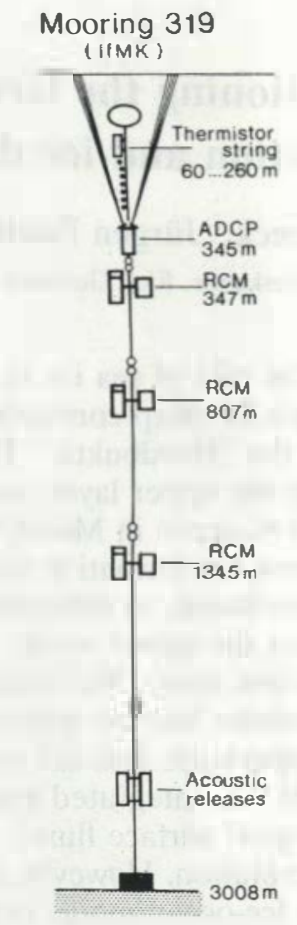

(b)

Figure 1. Grecnland Sca (a) mooring positions and (b) mooring design. Ice limits for three extremc periods during the winter of 1988/1989 and the location of the special sensor microwave/imager (SSM/1) ice section for Figurc 3 are included.

substantially [Vinje, 1977]. In particular, the opening of an ice free bay, named "Nordbukta," leaving the "Is Odden" behind, is of interest. The northeastward ice tongue Is Odden was already well known to whalers and scal hunters in the last century [Nansen, 1906; Krïmmel, 1911].

We will briefly revicw the evolution of the upper Greenland Sea gyrc, as observed during the winter 1988/1989, then evaluate the consequences of ice drift on mixed-layer dynamics, and finally, present a scenario of the Nordbukta formation that secms to be consistent with the evolution of the ice cover and upper ocean temperatures.

\section{Observations}

During the winter of $1988 / 1989$ a major investigation of the circulation, deepwater formation, and general hydrography of the Greenland Sea was carricd out within the framcwork of the Greenland Sea project [GSP Group, 1990]. Our group from Institut für Meereskundc (IfM) Kiel participated with five moored acoustic Doppler current profilers (ADCPs) to measure threc-dimensional velocity profiles. In particular, we were interested in the vertical velocity during convection events [Schott et al., 1993]. However, the thermal stratification of the upper $300 \mathrm{~m}$ was also documented by two thermistor strings and several temperature sensors of rotor current meter at two sites (319 and 250; see Figure 1). The two other moorings (T6 and T5; see Figure 1) were part of an acoustic tomographic array [Greenland Sea Tomography Group, 1993]. The shallow depth of the tomographic transceivers $(95 \mathrm{~m})$ prohibited deployment of upper occan thermistor strings and ADCPs in the upward looking mode at those moorings. However, valuablc time series of temperature and salinity were obtained by Seacats in the central tomographic mooring T6 [Roach et al., 1993]. See also a recent review of the tomographic results by Pawlowicz et al. [1995].

\subsection{Thermal Stratification}

The evolution of the thermal stratification at station 319 in the center of the GS, as seen by thermistor strings from 60-240 $\mathrm{m}$ depth, is displayed in Plate 1 . During the summer months the uppermost thermistor was located within in the seasonal thermocline (Plate 1). In October, significant cooling began, and by mid-November the surface waters ( $60 \mathrm{~m}$ depth) reached near-freezing temperatures. The mean temperature between 60 and $240 \mathrm{~m}$ depth decreased more slowly, and downward penetration of cold surface water into the warmer Arctic Intermediate Water (AIW) was observed (Plate I). The AIW itself is a mixture of the cold Arctic Surface Water (ASW) which resides in the central gyre and the warmer Atlantic Water (AW) toward the west [Carmack, 1986].

From early February onward all thermistors were located within the mixed layer. Intermediate convection down to 1500 m depth occurred in early March [GSP Group, 1990], and later on, rapid restratification was seen, as a series of warm and cold water masses encountered the mooring with a general warming trend. Note that this general picture was also seen in the slice inversion from the tomographic array [Greenland Sea Tomography Group, 1993; Pawlowicz et al., 1995] and hence seems to be characteristic for a larger region within the center of the Greenland Sea gyre.

In the Is Odden region at station 250, which was located 220 $\mathrm{km}$ to the southeast of station 319 , the evolution of the thermal 

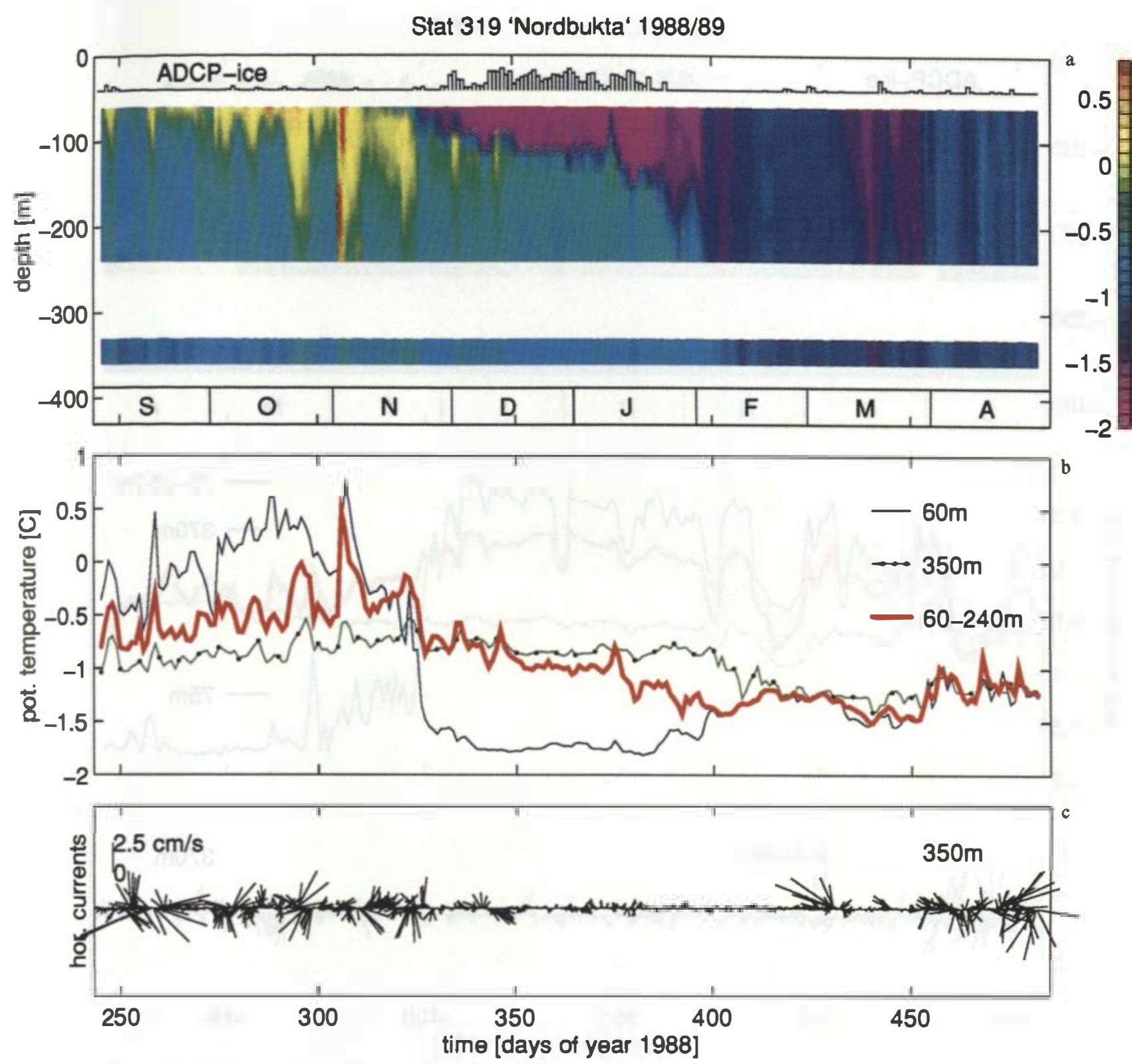

Plate 1. Evolution of (a) ice cover and thermal stratification, (b) temperature in 60 and $350 \mathrm{~m}$ depth and averaged between 60 and $240 \mathrm{~m}$ depth (bold line), and (c) 40-hour low-pass filtered horizontal currents in 340 $\mathrm{m}$ depth during winter $1988 / 1989$ at station 319 in the central Greenland Sea $\left(75^{\circ} \mathrm{N}, 5^{\circ} \mathrm{W}\right)$.

stratification was somewhat different (Plate 2). The warm AW was more prominent throughout the winter. Warm temperatures above $0^{\circ} \mathrm{C}$ in $80 \mathrm{~m}$ depth remained until early February, when the cold mixed layer reached the uppermost thermistor. The heat content continued to gradually decrease until midMay, when the instruments were recovered. In contrast to the central GS (station 319), the depth of the mixed layer in the Odden region never exceeded $150 \mathrm{~m}$.

\subsection{Ice Concentration, Wind, and Ice Drift}

The evolution of sea ice was deduced from the following two sources: special sensor microwave/imager (SSM/I) satcllite brightness temperatures and ADCP surface reflections. Daily maps of satellite ice concentration (L. Toudal, personal communication, 1992) gave insight into the spatial evolution of ice concentrations with a horizontal resolution of 30 to $50 \mathrm{~km}$ [Barry et al., 1993]. The presence of ice was also deduced from surface reflections of the ADCP pulses [Visbeck and Fischer, 1995 ] representative for only a small area $(<1 \mathrm{~km})$. However, on the basis of 2-day averages both data sets revealed a similar local evolution of the ice cover at the mooring sites.

Maximum ice concentration was found in early December 1988 at both stations. A series of consecutive satellite ice maps (Figure 2) show the opening of an ice free bay in the central GS (Nordbukta) during mid-January 1989, while the southeastern part remained ice-covered under the ice tongue Is Odden. A north-south section along $5^{\circ} \mathrm{W}$ displays the evolution of the ice concentration with daily resolution (Figure $3 \mathrm{a}$ ). The duration of the ice cover is minimum at $75^{\circ} \mathrm{N}$ (station 319), while at $73^{\circ} \mathrm{N}$ (closer to station 250) the ice forms earlier and extends well into March 1989.

Surface wind stress and air-sea fluxes were obtained from the model of the European Centre for Medium-Range 


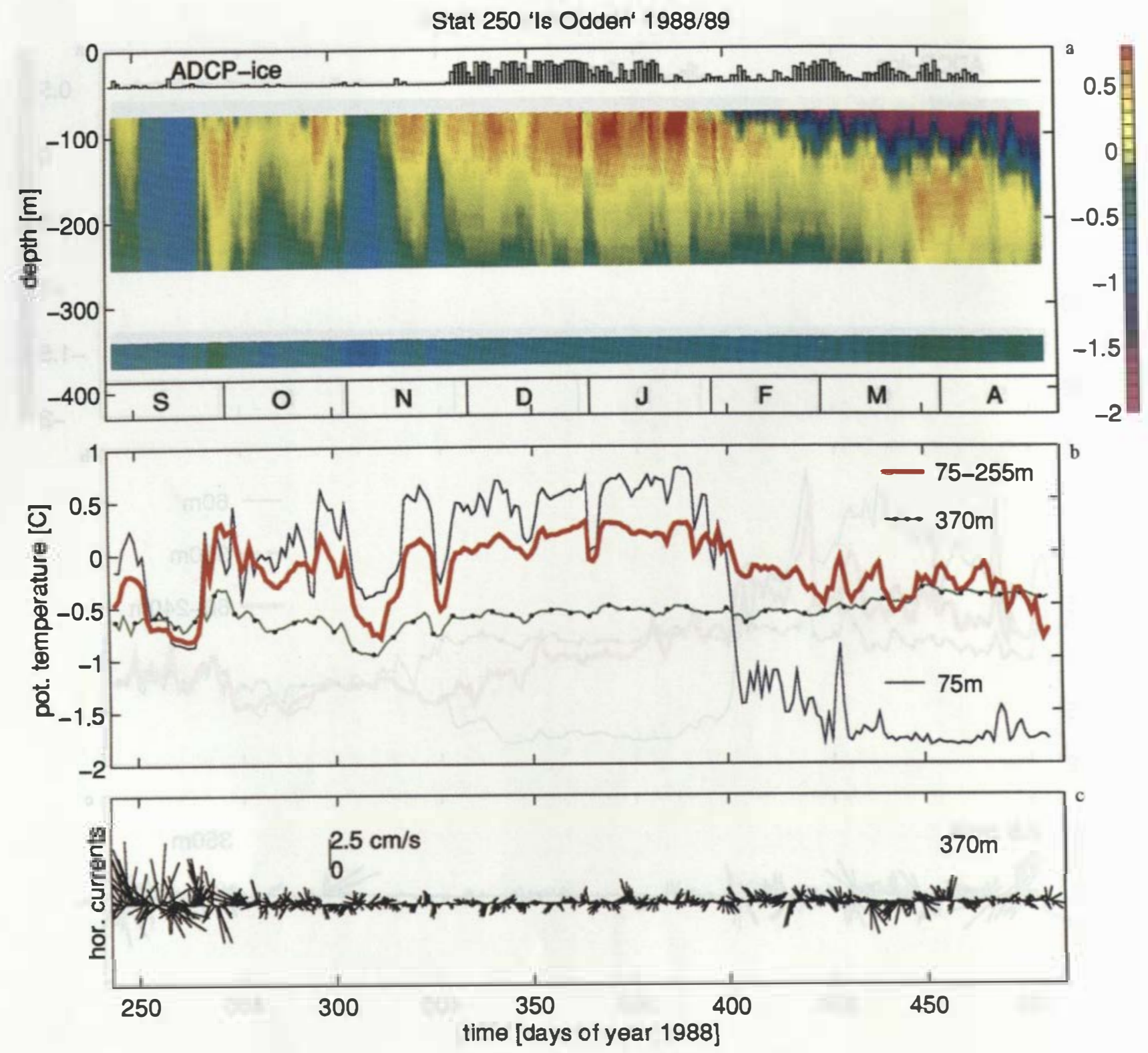

Plate 2. Same as Plate 1 , but for station 25() in the Is Odden region $\left(73^{\circ} \mathrm{N}, 1^{\circ} \mathrm{W}\right)$, with all instruments located approximately $20 \mathrm{~m}$ deeper.

Weather Forecasts $(E C M W F)$ on a $2^{\circ} \times 2^{\circ}$ resolution (K. Arpe, personal communication, 1991). The model winds were in general agreement with ship observations [Schott et al., 1993] and show a number of storm events during the winter, mostly from northerly directions (Figure 3c). The southward extent of the ice cover is responding to these storm events, indicating that the ice is, at least in part, driven by the wind. The winter mean winds are toward the southwest with a speed of approximately $5 \mathrm{~m} \mathrm{~s}^{-1}$. Using the rule of thumb that the ice drifts $1 / 50$ of the wind speed [Macklin, 1983] yields an ice drift speed of approximately $10 \mathrm{~cm} \mathrm{~s}^{-1}$. Unfortunately, ice drift cannot be deduced from SSM/I images because of the coarse spatial resolution. However, ice drift was directly measured by the upward looking ADCPs at both mooring sites (Figure 3c). The ice drift was well correlated with the ECMWF winds [Visbeck and Fischer, 1995], and the average ice drift over the winter month is toward the southwest with a speed of approximatcly $10 \mathrm{~cm} \mathrm{~s}^{-1}$ at both stations.

The ECMWF model also provided estimates of surfacc heat fluxes (Figure 3d). The average cooling of approximately 250 $\mathrm{W} \mathrm{m} \mathrm{m}^{-2}$ over the winter months is equally distributed between the sensible and latent fluxes and the long wave radiation, with a slight dominance of the sensiblc heat loss. However, the cstimates secm to bc somewhat large during the icc-covered period, most likcly due to the lack of a proper representation of ice cover in the ECMWF model.

\subsection{Stratification}

The central Greenland Sea is characterized by minimal vertical stability of the subsurfacc laycrs [Clarke et al., 199()]. However, the surfacc layers are quite stratified in late summer. when a warm and fresh surfacc layer is ovcrlaying the salty 


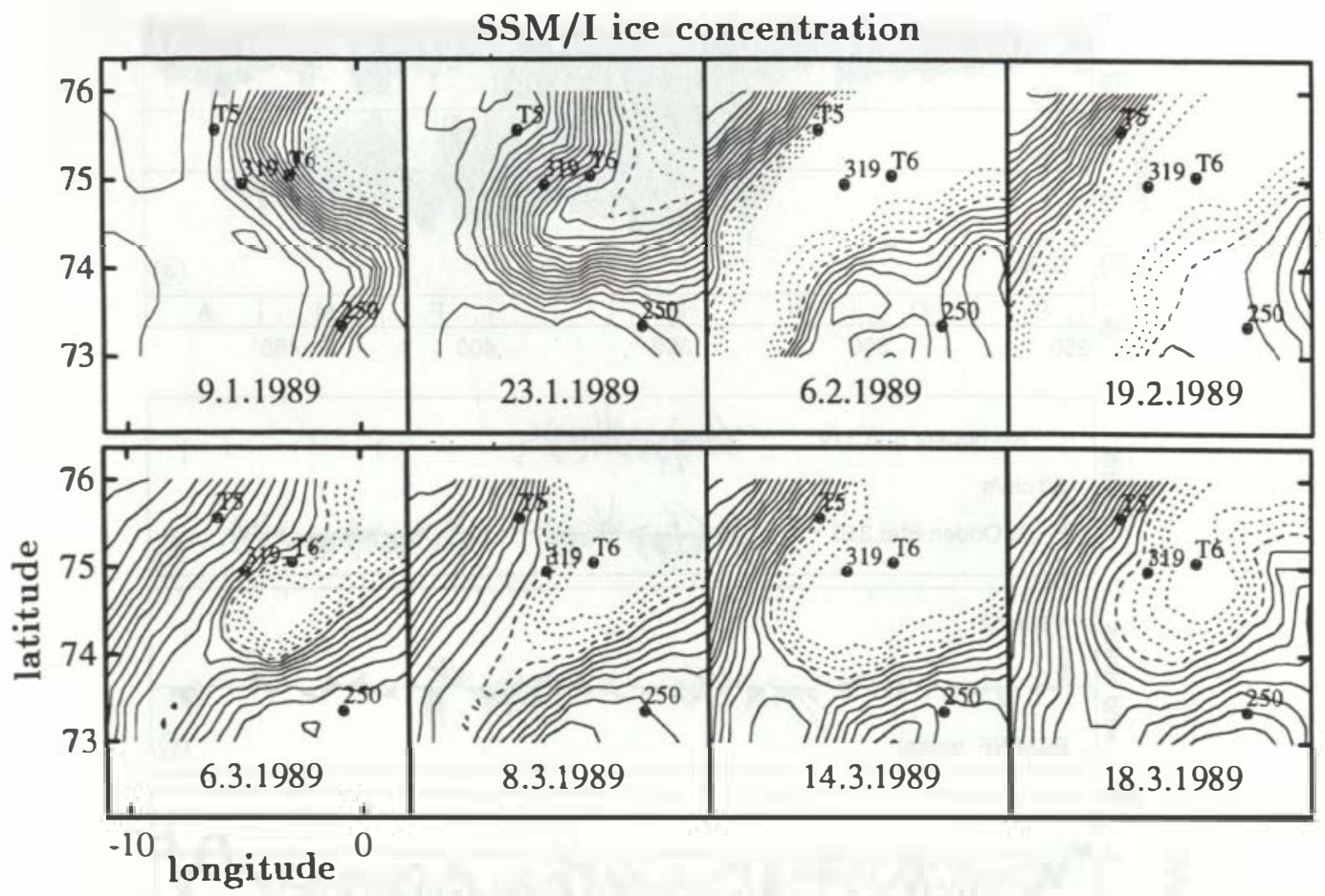

Figure 2. Ice concentration maps as deduced from SSM/I brightness temperatures (L. Toudal, personal communication, 1992). Dates of maps and locations of moorings are included. Contour interval is 5\%, and contour lines smaller than $25 \%$ ice concentration are dashed.

Arctic Intermediate Water (AIW). In November 1988, after the surface layer had cooled substantially, the stratification still remained stable due to a freshwater cap as a result of summer surface meltwater (Figure 4, solid curve). During the following winter months this fresh layer was eroded, and finally, deepmixed profiles down to $1500 \mathrm{~m}$ depth were observed in early March 1989 (Figure 4, dashed curve).

A rough estimate of the integrated surface fluxes can be ohtained from the difference in heat and freshwater content hetween hydrographic stations from November 1988 and March 1989. The difference in heat content corresponds to an average heat loss of approximately $150-200 \mathrm{~W} \mathrm{~m}^{-2}$ during the 12) days. The freshwater budget required about $1 \mathrm{~m}$ of new-ice formation to mix down to $300 \mathrm{~m}$. However, if deeper mixing occurred. less net ice formation was needed. Since the heat flux cstimate is well within the climatological range |Clarke et al., $199(0)$. a one-dimensional evolution was considered as a reasonable starting point to model the temporal evolution of the midgyrc stratification.

\subsection{Summary of the Observed Preconditioning During Winter 1988/1989}

Thermistor string and ice observations during the winter of 1988/1989 suggested the following scenario of preconditioning the upper ocean for deep or intermediate convection.

1. In autumn, heat loss to the atmosphere cools the warm summer surface temperatures toward the freezing point. Typical mixed-layer (ML) depths are in the range of 50 to $100 \mathrm{~m}$.

2. Further cooling yields local ice formation. Subsequent brine rejection reduces the mixed-layer buoyancy, and a gradual ML deepening of approximately $1 \mathrm{~m} \mathrm{~d} \mathrm{~d}^{\prime}$ was observed Brine rejection and entrainment of AIW cause a steady in crease of mixed-layer salinity, as seen by moored Seacats [Roach et al., 1993, Figure 2].
3. By the end of January 1989 the central GS is ice free again. The mixed-layer depth increased more rapidly, and by mid-February 1989, energetic convective plumes were found in the upper $300 \mathrm{~m}$ [Schott et al., 1993]. Intermediate convection down to approximately $1500 \mathrm{~m}$ occurred on March 6 and 16, 1989

Note that a similar evolution was seen in path 6-4 of the tomographic array [Pawlowicz et al., 1995]. However, during other winter seasons, deep or even intermediate convection events were missing. For example, during the winter 1989/1990 the upper ocean was not well preconditioned for deeper convection, because the mixed layer never penetrated through the AIW and remained shallower than $200 \mathrm{~m}$ [Visbeck, 1993]. For this study, however, we will focus on the winter season of 1988/1989, since there are quite a number of observations available. One might assume that this particular season represents other years when deep or intermediate convection occurred

The most outstanding feature in the evolution of the ice cover (Figures I and 2) is the appearance of the ice free bay leaving the ice tongue or ice island Is Odden behind. We were interested in mechanisms that form the ice free bay Nordbukta. Several scenarios come into mind or were proposed.

1. A deepening mixed layer entrains warm AIW and melts the previously formed ice. Consequently, a region of open water appears (melting scenario).

2. Strong winds blow the ice away to the southwest, and the cyclonic surface currents around the Greenland Sea gyre, in particular the Jan Mayen Current, advect ice from the East Greenland Current northeastward back into the ls Odden region (wind-current scenario)

3. Wind-forced ice drift with a mean direction toward the southwest removes a fraction of the locally formed ice through- 


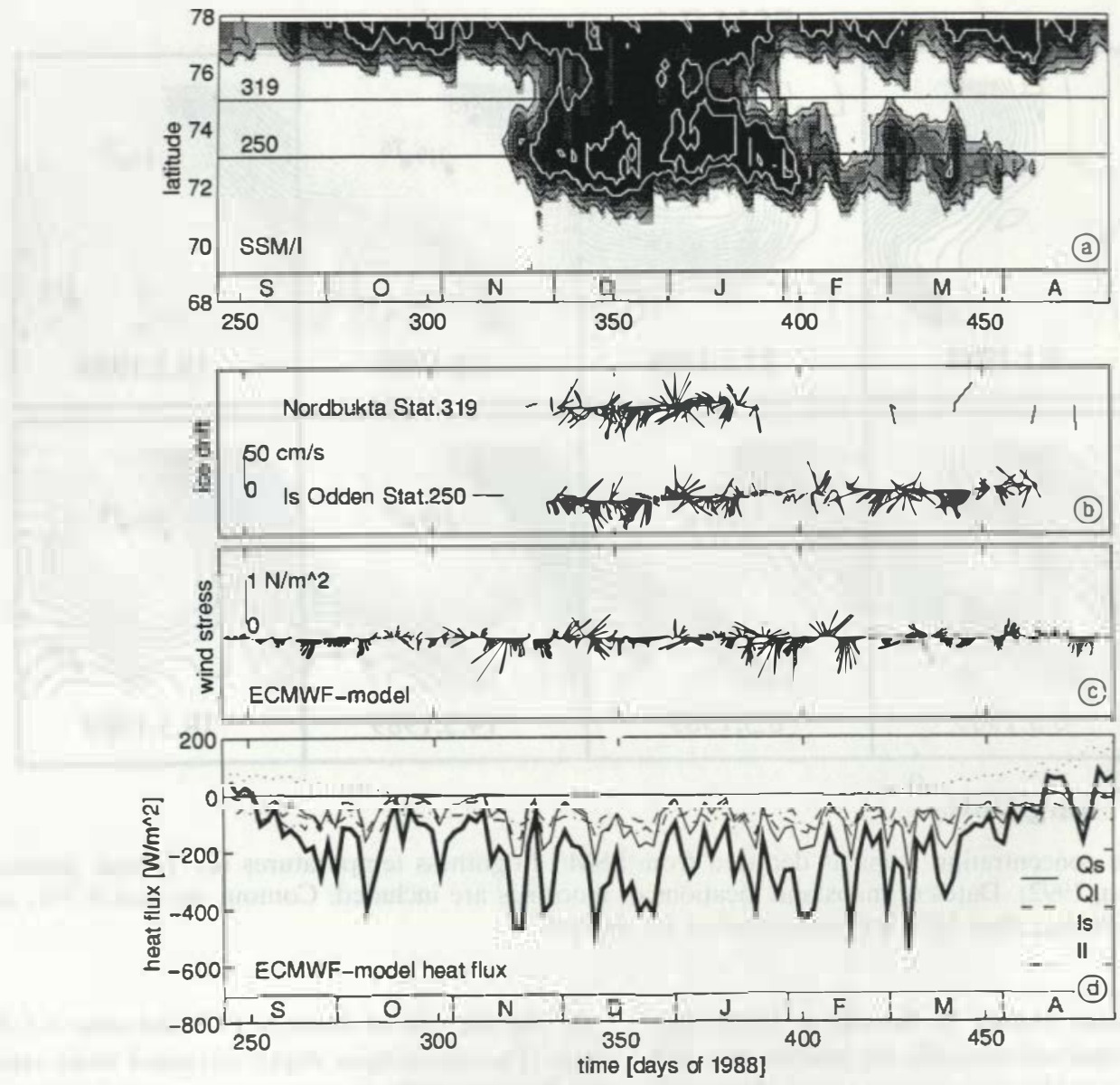

Figure 3. (a) North-south section of ice concentration along $5^{\circ} \mathrm{W}$ (see Figure 1 for location) versus time, as seen by the SSM/I (L. Toudal, personal communication, 1992). Contour interval is 20\%. (b) Ice drift as observed form upward looking acoustic Doppler current profilers (ADCPs) for two stations. (c) Wind stress from the European Centre for Medium-Range Weather Forecasts (ECMWF) model for the central Greenland Sea. (d) Heat flux components from the ECMWF model and their sum (bold line).

out the winter season. New ice formation replaces the "exported" ice locally and thereby sustains the ice cover. Consequently, salt accumulates in the mixed layer and enhances the convective mixed-layer deepening which, in turn, entrains warm and salty water from below. At some point, more heat can be entrained from below than is lost to the atmosphere. From then on, further new ice formation is prohibited and an ice free region occurs (ice-drift scenario).

The melting scenario requires a source of heat from below, which could be provided by the warm AIW layer between 100 and $300 \mathrm{~m}$ depth. However, there must be a mechanism to entrain the warm water into the mixed layer. Wind mixing will play a role initially when the mixed layer is shallow. However, for deep-mixed layers the wind stirring becomes less effective and convective mixing will become more important. Rudels [1990] suggested that a series of freezing-melting cycles are able to entrain the warm and salty water into the mixed layer. This might be a possible mechanism, but as we will see in the following, the resulting mixed-layer properties in the Nordbukta would be fresher and cooler than observed.

The wind-current scenario suffers from different problems. It seems unlikely that a mean wind pattern is such that it moves the ice southwestward in the central Greenland Sea and at the same time northeastward in the Odden region. Therefore one has to invoke ocean currents to move the ice back into the
Odden region if a large-scale wind pattern had shifted it southward in the first place. From ice drift (Figure 3b) and upper ocean current measurements (Plates 1 and 2 ) there is no indication of considerable difference between the mean ice drift in the Nordbukta and Is Odden regions. Moreover, the ice drift in the Odden region is in the wrong direction, toward the southwest. Finally, there should be multiyear ice present in the Odden if most of the ice is advected there from the East Greenland Current region. Neither the SSM/I data nor shipboard observations (P. Wadhams, personal communication, 1994) shows the presence of multiyear ice in the Odden.

The ice-drift scenario assumes that over the course of the winter, ice drifts to the southwest [Visbeck, 1993; Pawlowicz et al., 1995]. A large-scale ice drift, together with an ice volume gradient in the same direction, can yield a local export of ice which, in turn, yields a loss of total fresh water when integrated over the ice volume and upper ocean layers. The freshwater flux due to drifting ice, the ice volume times ice drift, is diver gent if the ice volume increases in the direction of the ice drift. As a consequence, the local ice volume does no longer represent all the fresh water taken out of the mixed layer at that location. In the central Greenland Sea the ice volume will be smaller compared with a no-ice-drift scenario, while toward the southwest in the East Greenland Current region, more ice should be found than was locally formed. In the following we 
use a one-dimensional ice-ocean model to investigatc some aspects of the melting and ice-drift scenarios in more detail.

\section{One-Dimensional Ice-Ocean Model}

We have used a one-dimensional mixed-layer model coupled to a thermodynamical ice model to investigate the evolution of the stratification in the Greenland Sea during the winter of 1988/1989. Killworth [1979] proposed a quasi-steady mixedlayer model to study similar convection problems. Pawlowicz et al. [1995] have applied this model to the region of interest and showed that ice export will increase the late winter mixed-layer depth significantly. Here we are interested in more details of this mechanism and have therefore used a time dependent version which also allowed for some form of wind mixing. Results from more complete ice-ocean models have been presented by Houssais and Hibler [1993], who studied the effect of convective mixing on the evolution of the ice cover in a twodimensional slab model along $75^{\circ} \mathrm{N}$. They were able to obtain a more realistic seasonal cycle of the ice cover when upper ocean convective mixing was included. However, ice drift in the north-south direction was not allowed for, which we found is a key process relevant to the icecover and mixed-layer properties in this region. Fully three-dimensional ice-ocean model results for the Arctic Ocean and the Greenland Sea were presented by Häkkinen [1993, 1995]. However, the spatial res olution was not sufficient to investigate the details of the central Greenland Sea region which are of interest here. We
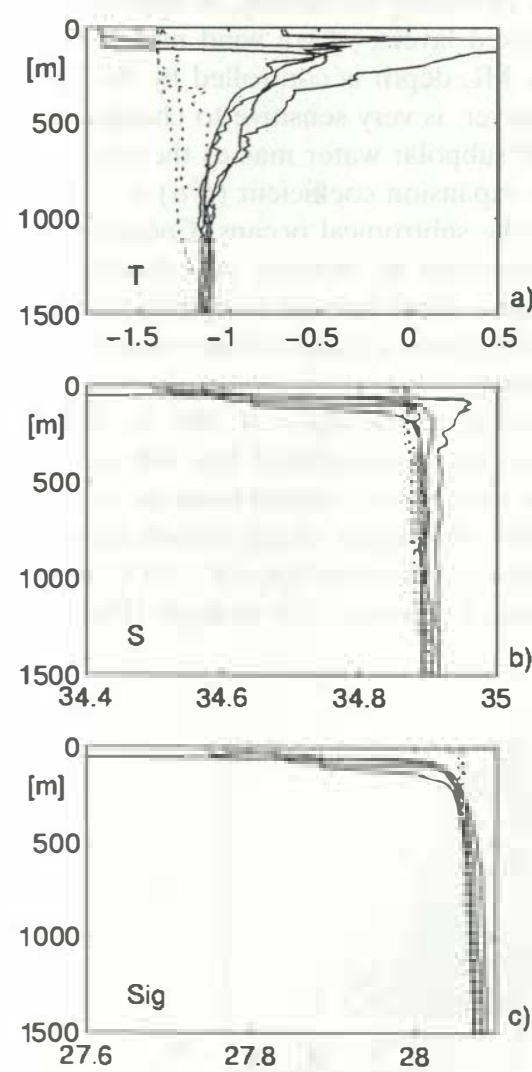

Figure 4. Hydrographic stations from the central Greenland Sea for November 1988 (solid lincs) and March 1989 (dashed lines) (D. Quadfasel and J. Meincke, personal communication, 1991) showing (a) potential temperature, (b) salinity, and (c) potential density referenced to the surfacc.
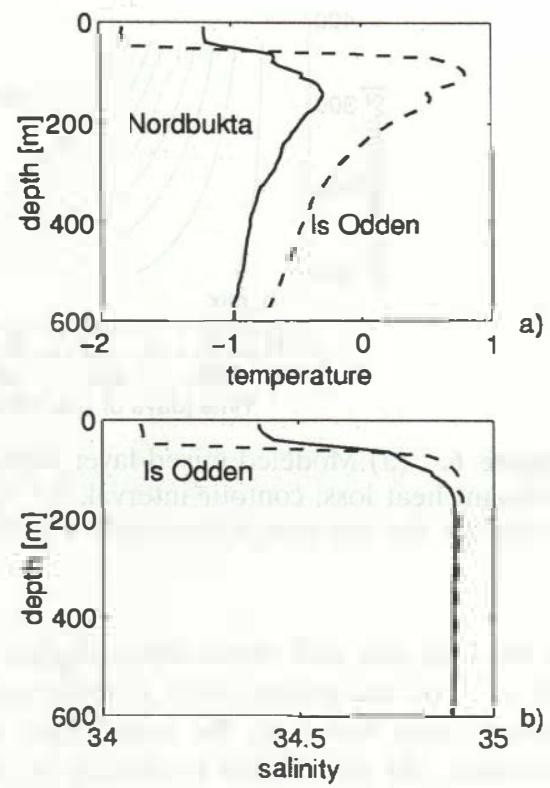

Figure 5. (a) Mean temperature and (b) salinity profilcs for the central Greenland Sea from November 1988 (solid lincs) and the Odden region from December 1988 (dashed lines) that werc used as initial conditions for the ice-ocean model.

preferred to use a model of intermediate complexity to investigatc the rolc of ice drift in the Nordbukta and Odden regions.

The mixed-layer model code, a Krauss-Turner type model, was kindly provided by Rahmstorf [1991], and the details of it are given in the appendix. We have modified his version by including a fully nonlincar cquation of state to compute the vertical stability at the base of the mixed layer. Further, a simple thermodynamical ice model was coupled to the ocean model (see appendix for details). The initial conditions were mean observed temperature and salinity profiles from Novembcr-Deccmber 1988. We first present the results for the central Greenland Sea, the region where the ice free bay occurred, and then show the evolution in the ice-covered Odden region.

\subsection{Central Greenland Sea}

The question we are addressing is: How much of the observed ice and upper ocean evolution is consistent with surfacc-forced onc-dimcnsional mixing? All experiments start with the same initial mean profiles from late November 1988 (Figure 5), and the realism or complexity of the surfaccs fluxcs will be gradually increased.

The first set of experiments consists of constant hcat, fresh water, and kinetic cnergy lluxes at the surfacc. The wind forcing was obtained from the ECMWF model winter period and corresponds to rms wind speeds of $9 \mathrm{~m} \mathrm{~s}^{-1}$. Evaporation and precipitation were also taken from the ECMWF model and amounted to $110^{-8} \mathrm{~m} \mathrm{~s}^{-1}$ net evaporation. The heat loss was varied bctween 100 and $350 \mathrm{~W} \mathrm{~m}^{-2}$. The resulting mixed-layer depths and icc thicknesses as a function of time and heat loss are displayed in Figure 6. There are several things to note. First of all, for reasonable heat loss values of 150 to $200 \mathrm{~W} \mathrm{~m}^{-2}$ the ice cover extends well into February-March, while the satcllite and ADCP ice observations show icc free periods much earlier on in late January. Further, the late winter mixed-layer depths are quite shallow, thereby indicating that not much of the warm AJW was entrained into the mixed layer. If $\mathrm{wc}$ are willing 

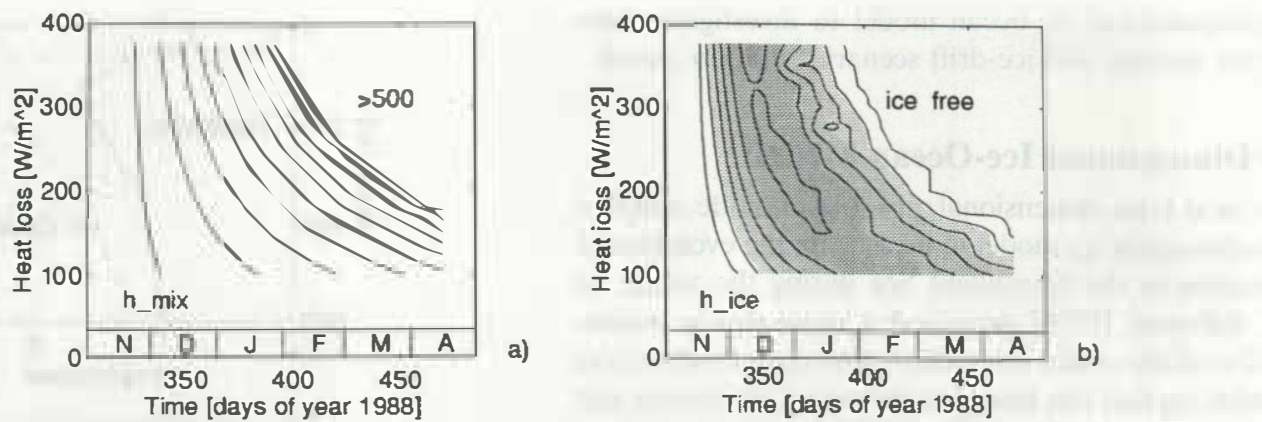

Figure 6. (a) Modeled mixed-layer depth evolution and (b) ice model thickness evolution versus imposed constant heat loss; contour interval, $0.1 \mathrm{~m}$. Regions of ice thickness exceeding $0.1 \mathrm{~m}$ are shaded. The time evolution was low-pass filtered with a 5-day cutoff.

to increase the heat loss well above climatological values toward $400 \mathrm{~W} \mathrm{~m}^{-2}$, we are getting closer to the observed duration of the ice cover. However, the mixed-layer depths are rapidly increasing and exceed $500 \mathrm{~m}$ already by the end of January which is much deeper than observed. Given the observed initial profiles, the ECMWF freshwater fluxes, and the onc-dimensional mixing physics, we have to conclude that ice formation, brine release, and later on, ice melt (icc melting scenario), give quite a different picture than the observations suggest.

We have to give up some constraints of the system in order to change the ice-ocean model evolution. We could question the initial TS profiles and the surface fluxes or allow for lateral oceanic advection/mixing. However, we have chosen to relax only the one-dimensional constraint for the icc cover but still demand a one-dimensional evolution in the ocean. The choice was motivated by icc-drift observations that show a signilicant mean ice drift to the southwest (Plate 1). As explained earlier, ice drift, together with an ice volume gradient, yiclds a reduction of mean ice thickness in the Nordbukta region. We have parameterized this effect by assuming a constant loss of ice thickness at each timc step (see appendix).

For the second set of experiments the same occanatmosphere fluxcs have been used with a fixed heat loss of 180 $\mathrm{W} \mathrm{m}^{-2}$. However, the ice export rate was varied between 0 and $10 \mathrm{~mm} \mathrm{~d}$ '. The results are presented in a similar manner as for the varying heat loss experiments (Figure 7). For ice exports between 5 and $7 \mathrm{~mm} \mathrm{~d}^{-1}$ the icc cover vanishes at about the right time in late January. Further, the mixed-layer depth increased gradually during the ice-covercd season and more rapidly from late February onward, both of which are consistent with the observations (Plate 1 ).

While it is obvious that the duration of the ice cover is reduced by the ice export, there are some interesting changes appearing in the evolution of the mixed-layer properties. Figure 8a displays the evolution of the mixed-layer temperaturc versus salinity for $1,3,5$, and $7 \mathrm{~mm} \mathrm{~d}^{-1}$ ice export rates. With increasing ice export the model trajectory gets warmer and saltier. The warming of the mixed layer shows up clearly when the mixcd-layer temperature is plotted against mixed-layer depth (Figure $8 \mathrm{~b}$ ). The ML temperature increases by up to $0.4^{\circ}$ for 300 - to $500-\mathrm{m}$ deep mixcd layers due to increasing ice export. The warm mixed layers are a consequence of the strong dependence of density on salinity, as opposed to temperature For deep mixed layers, where wind mixing becomes less important, the ML depth is controlled by the ML density. The density, however, is very sensitive to changes in salinity. Note that lor cold subpolar water masses the ratio of the haline to the thermal expansion coefficient ( $\boldsymbol{\beta} / \boldsymbol{c} \boldsymbol{r})$ is $\sim 20$, as opposed to 4 or less in the subtropical oceans. Consequently, substantial cooling is required to increase the density by temperature changes, while a small increase in salinity (due to brine release and ice export) yields a much warmer mixed layer of the samc depth or density.

Therefore the temperature of 200- to 500-m deep mixcd layers in the central Greenland Sca will serve as a sensitive indicator for fresh water removal from the ice-ocean system. In February 1989, thermistor string records showed a significant warming from near freezing toward $-1.4^{\circ} \mathrm{C}$, as the mixed layer deepened from 150 toward $350 \mathrm{~m}$ depth (Plate 1). This mixed-
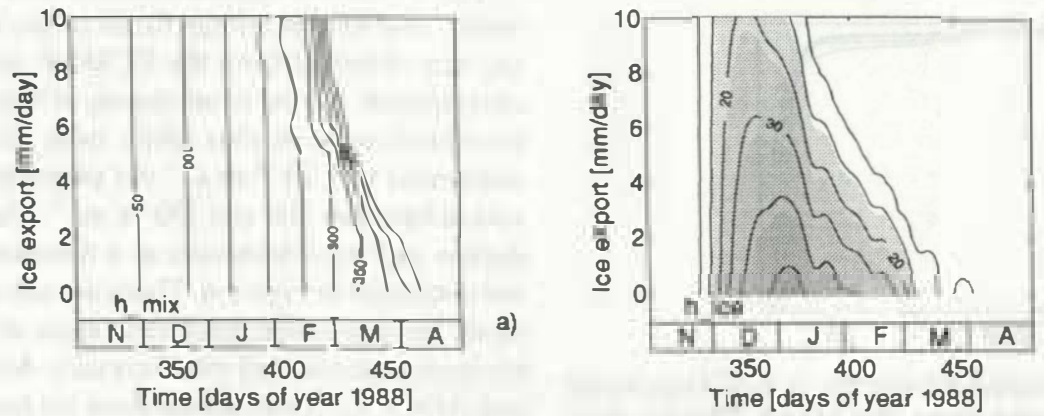

Figure 7. (a) Modeled mixed-layer depth evolution and (b) ice model thickness evolution versus constant ice export using a heat loss of $180 \mathrm{~W} \mathrm{~m}^{-2}$; contour interval, $0.1 \mathrm{~m}$. Regions of ice thickness exceeding $0.1 \mathrm{~m}$ are shaded. The time evolution was low-pass filtered with a 5-day cutoff. 

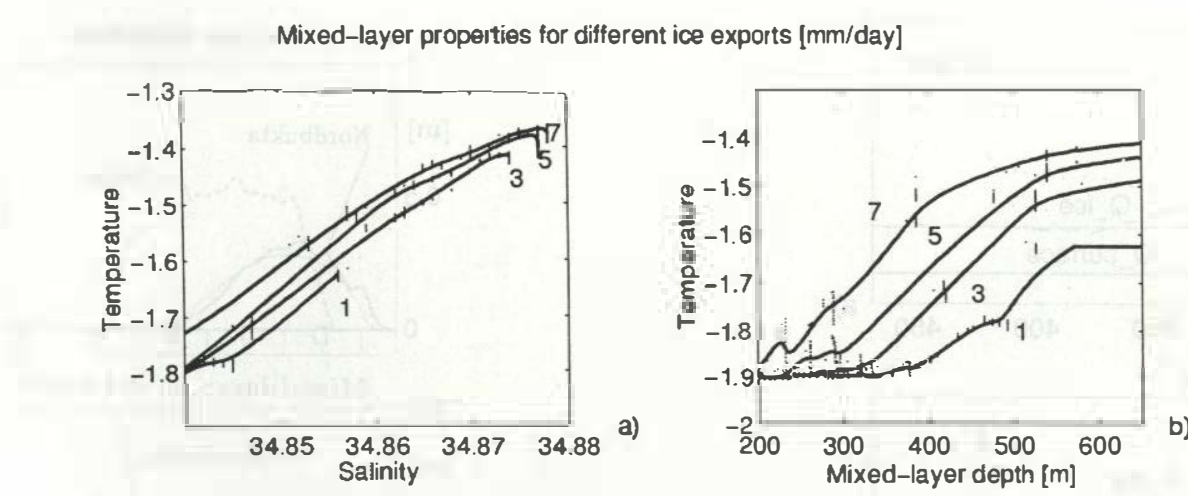

Figure 8. Time series of modeled mixed-layer temperature versus (a) salinity and (b) mixed-layer depth for different icc export rates $\left(1,3,5\right.$, and $\left.7 \mathrm{~mm} \mathrm{~d}^{-1}\right)$. Solid lines are low-pass filtered and connect individual points.

layer warming might be interpreted as an indication for freshwater loss due to ice export.

The mixed-layer model allowed us to inspect all fluxes that change the mixed-layer properties. The evolution of atmosphere-ocean and ice ocean surface fluxes and the entrainment flux at the base of the mixed layer are displayed in Figure 9. Initially. the mixed layer cools rapidly due to surface heat loss (Figure 9, solid curve). As the ML temperature approaches the frcezing point, some of the heat loss is used to form ice. By the end of December, not much more ice is formed and all the heat loss to the atmosphere is used to cool the warm water which is entrained from bclow. There was only marginal cooling from ice melt, since about three fourths of the ice was removed by the $5-\mathrm{mm}$ ice per day ice export. The freshwater flux is initially dominated by brine release due to new ice formation. However, entrainment contributes about one third to the steady salinity increase. From mid-December onward the changes in salinity are dominated by entrainment, with only minor modification due to melting ice. Both entrainment fluxes peak around carly March when the mixed layer is rapidly deepening and becoming warmer and saltier.

We have seen that the icc-ocean model evolution was closer to the obscrvations if wind-driven ice export was included. For the final set of expcriments the fluxes were allowed to vary in time. We have used the ECMWF model fluxes for a grid point close to mooring sitc 319. As can be seen from Figure 3d, the ECMWF model does not acknowledge the local ice cover very well. The fluxes should be somewhat smaller if sea ice is present (see Pawlowicz et al. [1995] for a discussion). As a somewhat ad hoc fix, the heat and freshwatcr fluxes werc reduced to a fraction of their original values if ice was present. By trial and error, an ice export ratc of $8 \mathrm{~mm} \mathrm{~d}{ }^{\prime}$ and a flux reduction to $60 \%$ under ice-covered conditions (Figurc 10) werc found to bring the ice-ocean model evolution close to the observations. The general agreement between observed and modeled mixed-layer depth is indicated in Figure $\mathrm{Il}$ by the cvolution of the maximum vertical tempcrature gradient. Moreover, thermistorstring temperatures from station 319 and Scacat temperatures and salinities from mooring T6 [Rouch et al.. 1993] (located approximately $60 \mathrm{~km}$ to the east of station 319) showed an evolution similar to the corresponding time series from the icc-ocean model (Figure 12).

We conclude that we could obtain a one-dimensional iceocean model run which looked somewhat like the observations when the effect of wind-driven ice export was included. We will now move on to the Odden region and investigate how the same amount of ice export is affecting the duration of the ice cover and upper ocean stratification there.

\subsection{Is Odden Region}

The ice-ocean model was next initialized with the observed stratification for the Odden region (Figure 5, dashed curve). Using the same timc-varying surface fluxes and ice export rates as for the central GS ( $8 \mathrm{~mm} \mathrm{~d}$ '), the ice cover of the Odden extended well into April, with ML depths of less than $200 \mathrm{~m}$ (Figure 10), both of which are consistent with the observations (Plate 2). Fresher surface waters and warmer and saltier AW prohibit rapid $\mathrm{ML}$ deepening in the Odden region. This implies that the freshwater loss due to ice drift, which had overturned the water column in the central GS to intermediate depths, was not strong enough to generate deep-mixed laycrs in the Odden region.

\section{Discussion}

The evolution of the thermal stratification in the central Greenland Sea was investigated, particularly the aspect of preconditioning the upper water column for deep convection. The winter of 1988/1989 served as a case study, since quite a few observations were available. The evolution of the ice cover might suggest that the ice frec bay Nordbukta is formed by extensive ice melt. However, investigating the effect of icc formation and ice mclt on the upper water mass properties yielded a different scenario: wintertime cooling causes new icc formation. The new ice is exposed to northcrly winds and drifts, on average, toward the southwest. In combination with a downwind ice-volume gradient, this can result in a local ice export. Wind-driven ice export is effectively a local freshwater flux divergence which, in turn, serves as an extra buoyancy loss. When the mixed layer has penctrated deep enough into the warm Arctic Intermediate Water, the upper ocean temperature becomes too warm and further new ice formation is prohibited. Now an ice free bay appears without much mclting involved, and the region is well preconditioned for thermally driven, deep-reaching convection. Therefore ice drift might be a key mechanism during the early winter months. when the mixed layers are preconditioned for late winter decp or intermediate convection in the central Greenland Sea.

It is an intcresting idea that the occurrence of the Nordbukta can serve as an indicator for advanced mixed-layer deepening, since we know that the upper layer within the Nordbukta was better preconditioned for decp convection than the mixed lay- 

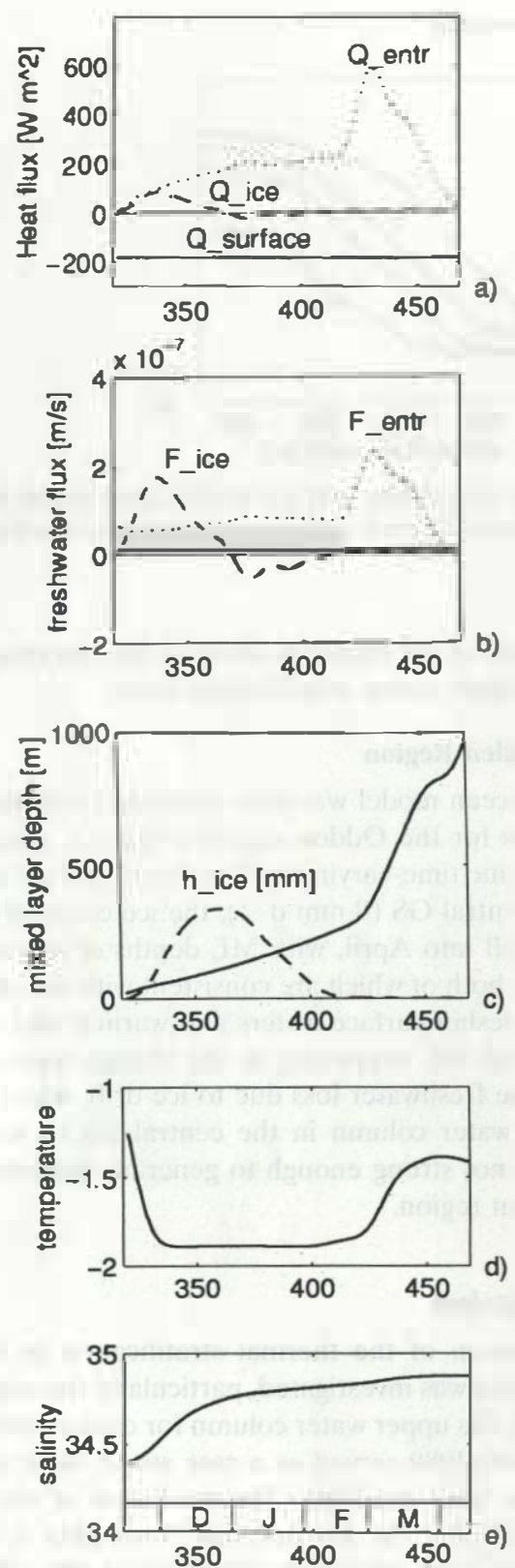

Fizure 9. Time series of mixed-layer model Huxes for the central Grecnland Sca. (a) Surface heat llux (solid line), heat of fusion (dashed line), and entrainment at the mixed-layer base (dotted line). (b) Evaporation minus precipitation (solid line), brine relcase (dashed line), and entrainment of fresh water (dotted line). (c) Mixed-layer depth (solid line) and ice thickness (dashed line) (in millimeters). (d) Mixed-layer temperature. (e) Salinity. All time series are low-pass liltered with a 10-day cutoft.

ers with sharp pycnoclines in the ice-covered periphery. On the basis of the same physical reasoning, Pawlowicz [1995] suggested that the ice volume in the central Greenland Sea might serve as an indicator for the occurrence of deep convection. However, his simple correlations showed only limited results.

Evidence for the proposed preconditioning scenario was gained from an ice-ocean mixed-layer model driven by surface fluxes. We could only produce a model run which was somewhat consistent with the observations of mixed-layer depth, ice-cover duration, and mixed-layer temperatures when an ice-
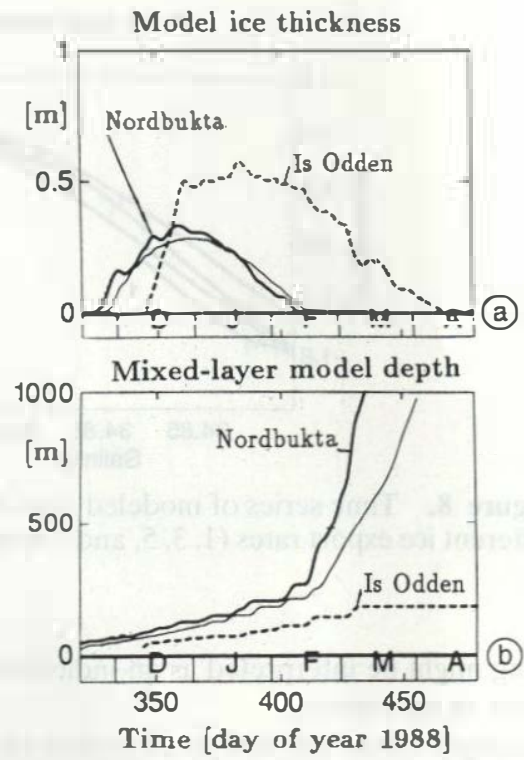

Figure 10. Time series of (a) ice model thickness and (b) mixed-layer depth for the following different surface fluxes and initial conditions: for the Nordbukta region, with constant heat loss of $180 \mathrm{~W} \mathrm{~m}^{2}$ and $5 \mathrm{~mm} \mathrm{~d}^{1}$ ice export (thin solid line), and using ECMWF time-varying fluxes with $8 \mathrm{~mm} \mathrm{~d}$ ' ice export and $40 \%$ flux reduction (bold solid line). The dashed line represents the Is Odden region with the same ECMWF forcing and ice export rate.
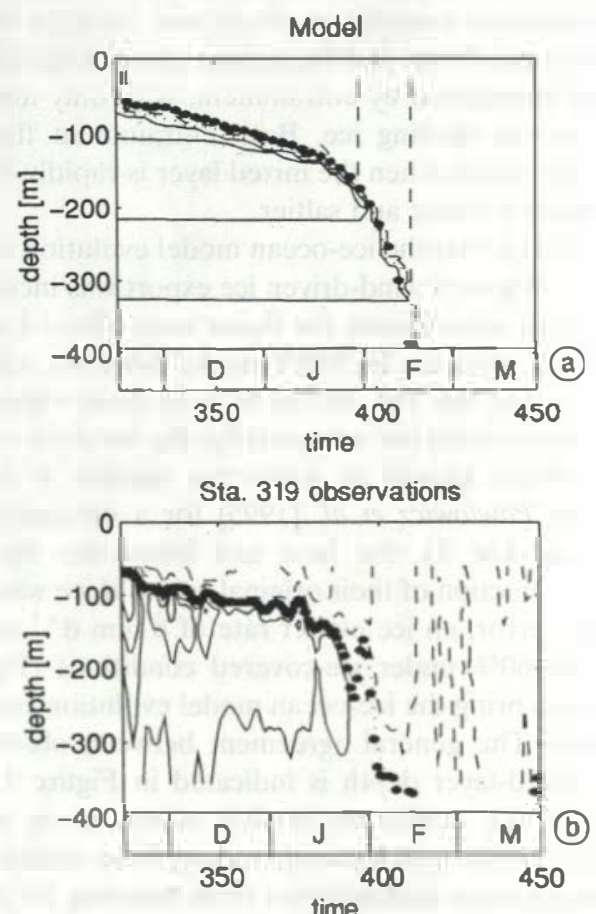

Figure 11. Contour of thermal stratitication from (a) the iceoccan model using corrected ECMWF fluxes and $8 \mathrm{~mm} \mathrm{~d} \mathrm{~d}^{-1}$ ice expurt and (b) thermistor string observations at station 319. Contour interval is $0.25^{\circ} ;-1^{\circ} \mathrm{C}$ contour is dotted; colder temperatures are dashed and warmer contours, solid. Maximum vertical temperature gradients are indicated by solid dots as a proxy for the mixed-layer depths. 


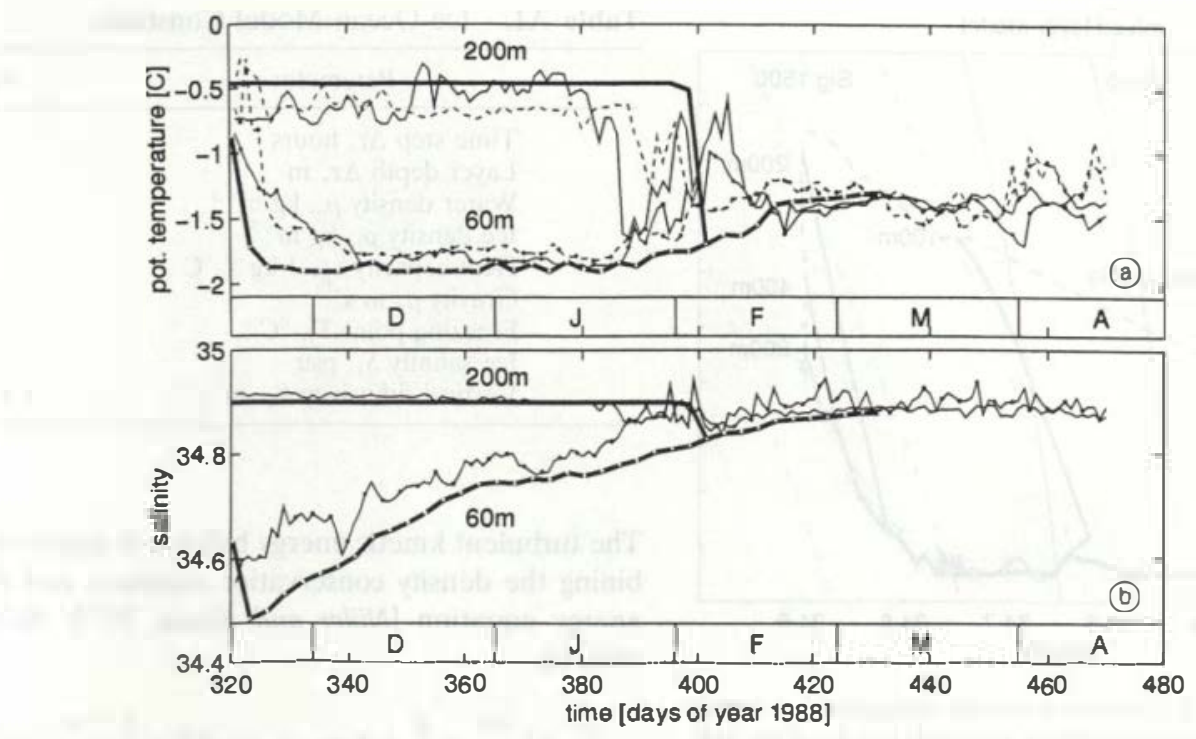

Figure 12. Time series of (a) temperature and (b) salinity at 60 and $200 \mathrm{~m}$ depth for the ice-ocean model (bold line) and from observations at station 319 (dashed line) and station T6 (thin solid line) [Roach et al., 1993]. Curves from $60 \mathrm{~m}$ depth have additional dots.

drift-induced ice export of 5-8 $\mathrm{mm} \mathrm{d}^{-1}$ was introduced. It was reassuring that the same amount of ice export did not remove the ice cover at the southeastern periphery of the GS gyre (Is Odden region) before April, as seen in ADCP and SSM/1 observations. Note that we have only investigated one area of the Odden region, and Bourke et al. [1992] showed some variability of upper layer TS properties along the Jan Mayen Current during September 1989. We suspect, however, that the qualitative mixed-layer evolution was similar in the other regions.

On the basis of ADCP ice-drift measurements, which showed a mean southwestward drift of $\sim 10 \mathrm{~cm} \mathrm{~s}^{-1}$, we thought it was sensible to investigate the role of drifting ice in altering the local freshwater budget. In order to obtain the required 5-8 $\mathrm{mm} \mathrm{d}^{-1}$ ice export, an ice volume gradient must be present in the direction of the ice drift. Given the mean drift speed of $10 \mathrm{~cm} \mathrm{~s}^{-1}$, a mean ice thickness gradient of $5-8 \mathrm{~cm}$ per $100-\mathrm{km}$ distance yields the required ice export. An alternative way of thinking about an ice volume gradient is by assuming that the region is only partly ice covered by ice floes of a constant thickness. If the floes are $30 \mathrm{~cm}$ thick, then the ice concentration must increase by $\sim 20 \%$ over $100 \mathrm{~km}$ to obtain the required mean ice thickness gradient. Both estimates are well within the range of reasonable numbers; for example, Wadhams [1992] found a mean ice thickness of 0.3-1 $\mathrm{m}$ in the Odden region during May 1987, but no such measurements were available for 1989 .

Note that, principally, a larger evaporation would have the same effect on the mixed-layer buoyancy budget as ice export had in our model. However, in order to obtain evaporative freshwater losses similar to $5-8 \mathrm{~mm} \mathrm{~d}^{-1}$ ice export, calculations, using standard bulk formulas to estimate the evaporation, suggest that either the average wind speed must have been well above $30 \mathrm{~m} \mathrm{~s}^{-1}$ or the relative humidity well below $50 \%$. Both parameter regimes are not very likely for atmospheric conditions in the central Greenland Sea; but given the sparse in situ observations, there is some uncertainty here, since we have mainly relied on weather forecast models.

We have further ignored any effect of lateral mixing in the ocean. This might not be a bad assumption between November and March, when the observed velocities showed minimal mean and fluctuating energy in the subinertial range. However, after intermediate convection had occurred, thermistor string temperatures showed increased variability and the current meter picked up stronger events (Plate 1). These signals suggest that mesoscale eddies, maybe generated around the convective region as a consequence of the deep mixing [Gascard, 1978], were penetrating into the region. Moreover, the heat budget considerations from Pawlowicz et al. [1995], which show a significant mismatch between the tomographically measured heat content and the integrated surface heat loss during March-April 1989, suggest that strong lateral mixing was taking place after the intensive mixing phase of early March 1989. During the previous month both estimates track quite nicely, which is consistent with a one-dimensional evolution.

The mixed-layer model enabled us further to inspect the evolution of the upper ocean temperatures versus salinity during the winter of $1988 / 1989$ (Figure 13). Similar figures have been produced from moored Seacat observations [Roach et al., 1993] and for conductivity-temperature-depth casts from the same winter [Pawlowicz et al., 1995] and are consistent with the following scenario: initial cooling reduced the ML temperatures toward the freezing point. Then brine release and entrainment increased the ML salinities until a critical mixedlayer salinity/density value was reached. We might call this phase "haline" convection, since the freshwater forcing is important. During this time, ice export is important, because it reduces the insulation of the surface waters from the atmosphere and removes some of the freshwater of the ice-ocean system. For the winter of 1988/1989 the critical ML salinity was close to 34.8 and was reached in late January 1989. From then on, surface cooling enhanced further convective mixed-layer deepening. We might call this phase "thermal" convection, since there is strong heat loss to the atmosphere, however, the overwhelming entrainment of warm water from below results in a mixed-layer warming despite surface cooling (see also Figure 9). Consequently, the region will remain ice free and the Nordbukta forms. 


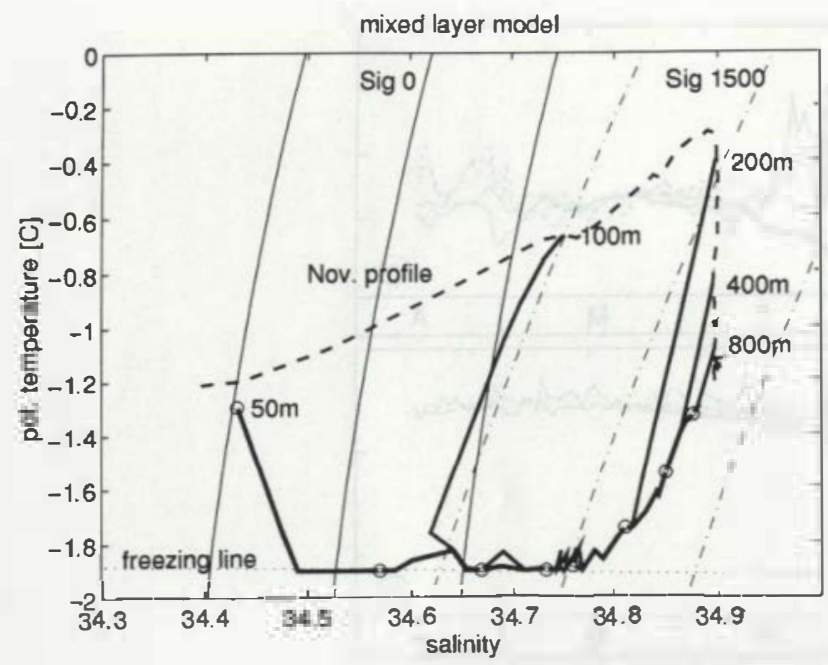

Figure 13. Evolution of ice-ocean model temperature versus salinity for the central Greenland Sea at depth levels of 50, 100, 200,400 , and $800 \mathrm{~m}$. The time evolution is indicated by a dot every 2 weeks. The mean observed stratification from November 1988 is represented by the dashed line, and several lines of constant density are included.

The series of one-dimensional ice-ocean model experiments highlighted the important role of sea ice and its drift in preconditioning the central Greenland Sea for intermediate or deep convection. Measuring the distribution of ice volume and ice drift would be helpful to quantify our indirectly estimated ice export rates. Moreover, monitoring the ice cover and surface winds, together with some hydrographic information about upper ocean freshwater content in late summer, would be useful to document and learn more about the variability of the convective activity in the central Greenland Sea.

\section{Appendix: Mixed-Layer Model}

We have used a Krauss-Turner [Kraus and Tumer, 1967] type mixed-layer model coupled with a thermodynamic sea ice model. The mixed-laycr model equations consist of tracer conscrvations (i.e., for temperature and salt):

$$
\frac{\partial \bar{\tau}}{\partial t}+\bar{w} \frac{\bar{\tau}}{\partial z}+\frac{\partial}{\partial t}\left(\overline{w^{\prime} t^{\prime}}\right)=0
$$

which, when integrated over the mixed-layer depth $h$, yields the well-known conservation cquations for heat and salt:

$$
\begin{aligned}
& h \frac{\partial T}{\partial t}+\Delta T w_{e}=-\frac{Q_{0}}{c_{\rho} \rho_{0}} \\
& h \frac{\partial S}{\partial t}+\Delta S w_{e}=S_{\theta}(E-P) .
\end{aligned}
$$

Here $\Delta T$ and $\Delta S$ denote the temperature and salinity jump at the base of the mixed layer, $Q_{0}$ is the surface heat fux, and $(E-P)$ is the surface freshwater flux. The entrainment velocity at the base of the mixed layer $w_{c}$ is given by

$$
\begin{array}{ll}
w_{c}=\partial h / \partial t \quad & \partial h / \partial t>0 \\
w_{c}=0 & \partial h / \partial t \leq 0 .
\end{array}
$$

Table Al. Ice-Ocean Model Constants

\begin{tabular}{lr}
\multicolumn{1}{c}{ Parameter } & Value \\
\hline Time step $\Delta l$, hours & 6 \\
Layer depth $\Delta z, \mathrm{~m}$ & 1.9 \\
Water density $\rho_{i}, \mathrm{~kg} \mathrm{~m}^{-3}$ & 1028 \\
Ice density $\rho_{i}, \mathrm{~kg} \mathrm{~m}^{3}$ & 950 \\
Heat capacity $c_{P_{2}, \mathrm{~J} \mathrm{~kg}^{-1}{ }^{\circ} \mathrm{C}}$ & 3989 \\
Gravity $g, \mathrm{~m} \mathrm{~s}^{\circ}$ & 9.81 \\
Freezing point $T_{f},{ }^{\circ} \mathrm{C}$ & -1.9 \\
Ice salinity $S_{i}$, psu & 9 \\
Vertical diffusivity $k_{z}, \mathrm{~m}^{2} \mathrm{~s}{ }^{-1}$ & $5 \times 10^{-5}$ \\
\hline
\end{tabular}

The turbulent kinetic energy balance is approximated by combining the density conservation equation and the mechanical energy equation [Niiler and Kraus, 1977; Rahmstorf, 1991], yiclding

$$
\frac{g}{2 \rho_{0}} h^{2} \frac{\partial \rho}{\partial t}+\frac{g}{\rho_{0}} h \Delta \rho w_{e}=-c_{1} U^{3}-\frac{1-c_{2}}{2} h B_{0} .
$$

The left-hand side can be interpreted as the rate of change of potential energy in the water column, where $B_{0}$ denotes the surface buoyancy flux

$$
B_{0}=\alpha \frac{g}{\rho_{0} c_{p}} Q_{0}+\beta g S_{\mathrm{ML}}(E-P)
$$

and $\Delta \rho$ is the density jump at the base of the mixed layer. Then $c_{1} U^{3}$ is the wind energy input, where we have used a depth dependent wind mixing coefficient $c_{1}=c_{1 e} \exp \left(-\boldsymbol{h} / c_{1 / 2}\right)$ with the same constants as Rahmstorf [1991]. The last term is the rate of decrease in potential energy due to dissipation of convective energy. The coefficient $c_{2}$ is 1 if the buoyancy flux is positive. In the case of buoyancy loss, a value of $c_{2}=0$ would represent a nonpenetrative convective process. Wc have chosen $c_{2}$ to be rather small (0.02), since the observations of deep-mixed density profiles showed no density jump at the base of mixed layers, which is indicative for bcing close to the nonpenetrative limit [Schott et al., 1994].

The density is computed using the full nonlinear equation of state:

$$
\rho_{\mathrm{ML}}=\rho\left(T_{\mathrm{ML}}, S_{\mathrm{ML}}, h\right) .
$$

The model is implemented on a finite difference grid, with 512 layers in the upper $1000 \mathrm{~m}$ depth. The time step was 6 hours, and for each time step the following procedure was carried out: (1) Apply the heat and freshwater exchange at the surface to the upper grid cell. (2) Compute a new density profile. (3) Check the potential density gradient at the base of the mixed layer, with the mixed layer depth as a reference depth. (4) If the profile is instable, mix the next grid cell into the mixed layer, then go to step 2 until a stable gradient at the base of the mixed layer is achieved. (5) Apply wind mixing and mixing due to convectively released potential energy. (6) Allow for some vertical diffusion. The constants used for the mixed-layer model are given in Table A1.

\section{A1. Ice Model}

We coupled a simple thermodynamic ice model to the mixcd-layer model. The change in ice thickness $h$, is determined by

$$
\partial \boldsymbol{h}_{i} / \partial t=Q_{i} / \boldsymbol{\rho}_{t} L_{f},
$$


where $L_{f}$ denotes the latent heat of fusion and $Q_{i}$ is the heat available to freeze or melt the ice:

$$
Q_{i}=c_{3} \frac{h_{\mathrm{ML}} c_{n}}{\Delta t}\left(T_{f}-T_{\mathrm{ML}}\right)
$$

If the mixed-layer temperature $T_{\mathrm{ML}}$ drops below the freezing temperature $\boldsymbol{T}_{f}$, then ice begins to form. The heat content of the mixed layer will be increased, and the ML temperature relaxes back toward the freezing point. Note that the salt budget (A3) is also changed due to brine release, and an extra contribution $\left(S_{\mathrm{ML}}-S_{i}\right) \partial h_{i} / \partial t$ appears. If the mixed-layer temperature rises above the freezing point, ice can be melted which cools and freshens the upper layer. We have assumed that the ice cover is fairly loose (pancake ice or loose pack) and never completely insulates the ocean surface from the atmosphere. However, for some runs the atmosphere-ocean fluxes were reduced to a fraction of the no-ice values if ice was present. Note that a more complete ice model must be considered for other more solid types of ice.

As seen by others [Welander, 1977; Killworth, 1979], the coupled ice-ocean model showed freezing-melting cycles which were kept minimal by adjusting $c_{3}$. A satisfying behavior was found for values of $c_{3}=0.8$. The constants used for the ice model are given in Table AI.

\section{A2. Ice Drift}

We have parameterized the local effect of ice drift in the ice model. If there exists an ice volume gradient along the ice-drift direction, then ice drift can give rise to a local change in ice thickness:

$$
\frac{\partial h_{i}}{\partial t}+\frac{\partial\left(u_{i} h_{i}\right)}{\partial x}=\frac{Q_{t}}{L_{f} p_{i}} .
$$

We have parameterized the ice export using a constant loss of ice thickness $\Delta h_{i, \mathfrak{r} x}$ per time step $\Delta t$ when ice was present

$$
\frac{\partial\left(u_{i} h_{i}\right)}{\partial x}=\frac{\Delta h_{i, e x}}{\Delta t}=\text { const. }
$$

Acknøwledgments. A number of people (K. Aagaard, B. Rudels, D. Quadfasel, V. Strass, R. Pawlowic2, M. Rhein, and U. Send) have contributed to this study over the past few years during discussions on the cause and physics of deep convection in the Greenland Sea. F. Carsey, P. Wadhams, and an anonymous reviewer provided helpful comments on an earlier manuscript. S. Rahmstorf kindly offered his mixed-layer model code. D. Quadfasel and J. Meincke contributed by generously offering CTD data, A. Roach and K. Aagaard allowed us to inspect and replot their Seacat time series, and L. Toudal provided valuable SSM/1 ice concentrations. This study was supported by the German Bundesministerium für Forschung und Technologie (BMFT) under grants MFG 0017-8, 03R 617, and 03PL002A; M.V. is presently funded by a NOAAVCAR postdoctoral fellowship.

\section{References}

Barry, R., J. Maslanik, K. Steffen, R. Weaver, V. Troisi, D. Cavalieri, and S. Martin, Advances in sea-ice research based on remotely sensed passive microwave data, Oceanography, 6(1), 4-12, 1993.

Bourke, R., R. Paquette, and R. Blythe, The Jan Mayen current of the Greenland Sea, J. Geophys Res., 97, 7241-7250, 1992.

Carmack, E., Circulation and mixing in ice-covered waters, in The Cersphysics of Sea Ice, edited by N. Untersteiner, pp. 641-712, Plenum, New York, 1986

Carmack, E., and K. Aagaard, On the deep water of the Greenland Sea. Deep Sea Res., 20, 687-715, 1973.

Clarke, R., J. Swift, J. Reid, and K. P. Koltermann, The formation of
Greenland Sea Deep Water: Double diffusion or deep convection?, Deep Sea Res., Part A, 37, 1385-1424, 1990.

Gascard, J., Mediterranean deep water formation, baroclinic instabilities and oceanic eddies, Oceanol. Acta, 1, 3I5-330, 1978.

Greenland Sea Tomography Group, Ocean acoustic tomography in the Greenland Sea, Geophys. Res. Lett., 20, 2211-2214, 1993.

GSP Group, The Greenland Sea Project-A venture toward improved understanding of the oceans' role in climate, Eos Trans. AGU, 71, 750-751, 754-756, 1990.

Häkkinen, S., Upwelling at the ice edge: A mechanism for deep water formation?, J. Geophys. Res, 92, 5031-5034, 1987.

Häkkinen, S., An Arctic source for the Great Salinity Anomaly: A simulation of the Arctic ice-ocean system for 1955-1975, J. Geophys. Res., 98, 16,397-16,410, 1993.

Häkkinen, S., Simulated interannual variability of the Greenland Sea deep water formation and its connection to surface forcing, J. Geophys. Res., 100, 4715-4726, 1995.

Houssais, M.-N., and W. Hibler, Importance of convective mixing in seasonal ice margin simulations, J. Geophys. Res., 98, 16,427-16,448, 1993.

Killworth, P., On "Chimney" formations in the ocean, J. Phys. Oceanogr., 9, 531-554, 1979.

Killworth, P., Deep convection in the world ocean, Rev Geophys., 2l(1), 1-26, 1983.

Kraus, E. B., and T. S. Turner, A one-dimensional model of the seasonal thermocline, II, The general theory and its consequences, Tellus, 19, 98-106, 1967.

Krümmel, O., Handbuch der Ozeanographie, J. Engelhorns Nachfolger, Stuttgart, Germany, 1911.

Macklin, S., Wind drag coefficient over first-year sea ice in the Bering Sea, J. Geophys. Res., 88, 2845-2852, 1983.

McDougall, T., Greenland Sea bottom water formation: A balance between advection and double-diffusion, Deep Sea Res., Part A, 30 , 1109-1117, 1983.

Nansen, F., Northern waters: Captain Roald Amundsen's observations in the Artic Seas in 1901. With a discussion of the origin of the buttum-waters of the Northern Seas, Skr. Nor Vidensk. Akud. Kl. 1: Mat.-Naturvidensk. Kl, 3, 1906.

Niiler, P., and E. Kraus, One-dimensional models of the upper ocean, in Modelling and Prediction of the Upper Layers of the Ocean, pp. 143-179, Pergamon, Tarrytown, N. Y., 1977.

Pawlowicz, R., A note on seasonal cycles of temperature and salinity in the upper waters of the Greenland Sea gyrc from historical data, $J$. Geophys Res., 100, 4715-4726, 1995.

Pawlowicz, R., J. Lynch, W. Owens, P. Worcester, W. Morawitz, and P. Sutton, Thermal evolution of the Greenland Sea gyre in 19881989, J. Geophys. Res., 100, 4727-4750, 1995.

Rahmstorf, S., A zonal-averaged model of the ocean's response to climatic change, J. Geophys. Res., 96, 6951-6963, 1991.

Rhein, M., Ventilation rates of the Greenland and Norwegian Seas derived from distributions of the chlorofluoromethanes FII and F12, Deep Sea Res., Part A, 38, 485-503, 1991.

Roach, A., K. Aagaard, and F. Carsey, Coupled ice-ocean variability in the Greenland Sea, Atmos. Ocean, 31, 319-337, 1993.

Rudels, B., Haline convection in the Greenland Sea, Deep Sea Res., Part A, 37, 1491-1511, 1990.

Rudels, B., D. Quadfasel, H. Friedrich, and M.-N. Houssais, Greenland Sea convection in the winter of 1987-1988,J. Geophys. Res., 94, 3223-3227, 1989.

Schott, F., M. Visbeck, and J. Fischer, Observations of vertical currents and convection in the central Greenland Sea during the winter of 1988/1989, J. Geophys. Res., 98, 14,401-14,421, 1993.

Schott, F., M. Visbeck, and U. Send, Open ocean deep convection, Mediterranean and Greenland seas, in Ocean Processes in Climate Dynamics: Global and Mediterranean Examples, edited by P. Malanotte-Rizzoli and A. Robinson, pp. 203-225, Kluwer Academic, Norwell, Mass., 1994.

Vinjc, T., Sea ice conditions in the European sector of the marginal seas of the Arctic, 1966-75, Aarb. Nor. Polarinst., 1975, 163-174, 1977.

Visbeck, M., Konvektion im offenen Ozean. Interpretation von Beobachtungen aus der Grönlandsee und dem westlichen Mittelmeer., Tech. Rep. 237, Inst. für Meereskunde, Kiel, Germany, 1993.

Visbeck, M., and J. Fischer, Sea surface conditions remotely sensed by upward-looking ADCPs, J. Atmos. Oceanic Technol., 12, 141-149, 1995. 
Wadhams, P., The ice cover in the Greenland and Norwegian Seas, Rev. Geophys., 19, 345-393, 1981.

Wadhams, P., Sea ice thickness distribution in the Greenland Sea and Eurasian Basin, J. Geophys. Res., 97, 5331-5348, 1992.

Welander, P., Thermal oscillations in a fluid heated from below and cooled to freezing from above, Dyn. Atmos. Oceans, 1, 215-223, 1977.

J. Fischer and F. Schott, Institut für Meereskunde, Düsternbrooker Weg 20, D-24105 Kiel, Germany.
M. Visbeck, Center for Meteorology and Physical Oceanography, Massachusetts Institute of Technology, Cambridge, MA 02139-4307. (e-mail: visbeck@plume.mit.edu)

(Received November 15, 1994; revised May 3, 1995; accepted May 9, 1995.) 